\title{
PENINGKATAN KEMAMPUAN GURU DALAM MENYUSUN RPP MELALUI DISKUSI KELOMPOK KERJA GURU (KKG) DI SD NEGERI 166324 TEBING TINGGI
}

\author{
Deliana Tambunan \\ Surel: delianatambunan@gmail.com
}

\begin{abstract}
ABSTRAK
Penelitian ini bertujuan untuk mengetahui apakah keterampilan guru di SDN 166324 Tebing Tinggi dapat meningkat dalam menyusun dan mengembangkan RPP melalui Kelompok Kerja Guru, cara meningkatkan kemampuan guru di SDN 166324 Tebing Tinggi dalam menyusun dan mengembangkan RPP melalui Kelompok Kerja Guru, dan menganalisis bagaimana guru di SDN 166324 Tebing Tinggi menyikapi relevansi penerapan Kelompok Kerja Guru dalam menyusun dan mengembangkan RPP. Subjek penelitian berjumlah 45 guru. Metode penelitian yaitu Penelitian Tindakan Sekolah (school action research). Hasil penelitian diperoleh nilai rata-rata sebesar $48,2 \%$ terhadap kemampuan dalam mempersiapkan pengadaan kegiatan belajar mengajar di SDN 166324 Tebing Tinggi dan termasuk kategori Sedang.
\end{abstract}

Kata Kunci : Diskusi, Kelompok Kerja Guru, RPP

\section{PENDAHULUAN}

Mengajar sebagai profesi
menjadikan tugas guru secara
langsung menyentuh manusia yang
berhubungan dengan kepentingan
dan kebutuhannya tumbuh dan
berkembang kearah kedewasaan dan
kemandirian melalui proses
pembelajaran. Pengajaran yang dilakukan oleh guru dilaksanakan dalam interaksi edukatif antara guru dan murid yaitu antara keadaan internal dan proses kognitif siswa. Fungsi guru dalam proses belajar mengajar adalah sebagai komunikator yang menghubungkan antara murid dengan guru.

Dengan demikian, seorang guru dalam menjalankan tugasnya harus mampu berkomunikasi dengan baik terhadap muridnya, melakukan kajian sederhana khususnya dengan pengenalan anak, menulis hasil kajiannya, menyiapkan segala sesuatunya yang berhubungan dengan persiapan mengajarnya, termasuk siap tampil menarik dan bertingkah laku sebagai guru, menguasai ilmunya dan siap menjawab pertanyaan dari anak didiknya, menyajikan materi ajar secara konkrit. Untuk itu dituntut kreativitas dan keprofesionalan guru serta menjunjung tinggi etika guru dan dedikasi yang tinggi untuk melaksanakan tugas keguruannya.

Jika hal ini dilakukan oleh masing-masing guru maka benarlah bahwa pekerjaan guru adalah pekerjaan profesional yang tidak mungkin dapat dilakukan oleh orang lain. Tugas guru tidak hanya sebagai 
profesi, tetapi juga sebagai suatu tugas kemanusiaan dan kemasyarakatan. Proses kognitif tersebut menghasilkan suatu hasil belajar yang terdiri dariinformasi verbal, keterampilan intelektual, keterampilan motorik, dan siasat kognitif. Oleh karena itu, guru menempati posisi yang lebih penting karena ia akan membawa muridmuridnya ke arah tujuan yang telah ditetapkan. Salah satu upaya agar guru mampu memerankan dirinya sebagai fasilitator pembelajaran yaitu dengan kemampuan guru untuk mengembangkan rencana pembelajaran sebelum melaksanakan tugasnya. Kemampuan guru merencanakan pembelajaran merupakan awal terciptanya pembelajaran yang aktif, kreatif, efektif, dan menyenangkan dikaitkan dengan konteks pembelajaran yang dilaksanakan di sekolah, masih banyak ditemukan pembelajaran yang bersifat teacher centered dan verbalisme. Guru mengajar hanya untuk menyampaikan pengetahuan kepada peserta didik yang berarti tujuan belajar yang diperoleh peserta didik hanya sekedar ingin mendapatkan atau menguasai pengetahuan saja. Hal semacam inilah yang membuat suatu kecenderungan anak menjadi pasif karena hanya menerima informasi atau pengetahuan yang diberikan oleh gurunya. Selain itu, pembelajaran demikian dapat menyebabkan kecenderungan lemahnya pengembangan potensi diri siswa dalam pembelajaran sehingga tidak mencapai standar kompetensi yang diharapkan.

Selama pembelajaran, guru belum memberdayakan seluruh potensi siswa sehingga sebagian besar siswa belum mencapai kompetensi individual yang diharapkan untuk mengikuti pelajaran berikutnya. Tidak dapat dielakkan pula, selama pembelajaran berlangsung, kelihatan beberapa siswa hanya duduk terdiam tanpa minat belajar dan aktivitas, melamun hanya mendengarkan penjelasan guru bahkan sebagian besar siswa belum belajar sampai pada tingkat pemahaman.

Hasil supervisi di SDN 166324 Tebing Tinggi pada bulan Oktober 2012 menunjukkan bahwa dari 41 guru hanya 12 orang yang menyusun RPP sendiri, yang lainnya memiliki RPP yang telah disusun oleh penerbit tertentu, ada yang memfotokopi dari teman, ada yang mendaur ulang dari internet bahkan ironisnya ada yang tidak memiliki RPP, padahal sebagian guru di kecamatan ini sudah mendapat gelar guru profesional karena sudah lulus sertifikasi, dan bisa dipastikan hampir $80 \%$ guru dalam melaksanakan pembelajaran belum menguasai program pengajaran yang dimilikinya. Berdasarkan fakta inilah, penulis sekaligus sebagai 
Pengawas Sekolah di SDN 166324 Tebing Tinggi termotivasi untuk meneliti, apakah kemampuan guru di SDN 166324 Tebing Tinggi dapat ditingkatkan dalam menyusun RPP melalui Kelompok Kerja Guru ?

Berdasarkan latar belakang masalah yang berkaitan dengan upaya meningkatkan kemampuan guru dalam mengembangkan RPP maka masalah yang akan diteliti dirumuskan sebagai berikut :

1. Apakah keterampilan guru di SDN 166324 Tebing Tinggi dalam menyusun dan mengembangkan RPP dapat ditingkatkan melalui Kelompok Kerja Guru ?

2. Bagaimana guru di SDN 166324 Tebing Tinggi menyikapi relevansi penerapan metode Kelompok Kerja Guru untuk meningkatkan keterampilan guru di SDN 166324 Tebing Tinggi dalam menyusun dan mengembangkan RPP?

Adapun yang menjadi tujuan penelitian ini adalah:

1. Untuk mengetahui apakah keterampilan guru di SDN 166324 Tebing Tinggi dapat meningkat dalam menyusun dan mengembangkan RPP melalui Kelompok Kerja Guru.

2. Mengetahui cara meningkatkan kemampuan guru di SDN 166324 Tebing Tinggi dalam menyusun dan mengembangkan RPP melalui Kelompok Kerja Guru.
3. Menganalisis bagaimana guru di SDN 166324 Tebing Tinggi menyikapi relevansi penerapan Kelompok Kerja Guru dalam menyusun dan mengembangkan RPP.

Hasil penelitian diharapkan dapat bermanfaat sebagai berikut:

1. Bagi Siswa

a. Penelitian ini bermanfaat bagi siswa karena dapat meningkatkan kualitas ilmu pengetahuan yang diajarkan oleh guru.

b. Meningkatkan kecerdasan siswa karena memperoleh pengetahuan dari guru yang mempersiapkan dengan baik bahan pengajarannya.

c. Meningkatkan ketuntasan dan prestasi belajar siswa.

2. Bagi guru

a. Penelitian ini bermanfaat bagi guru karena memberikan informasi dan konstribusi untuk meningkatkan kemampuan guru di SDN 166324 Tebing Tinggi dalam menyusun dan mengembangkan RPP melalui Kelompok Kerja Guru.

b. Memberi konstribusi bagi guru tentang upaya-upaya yang dapat dilakukan untuk meningkatkan keterampilan mereka dalam menyusun dan mengembangkan RPP melalui Kelompok Kerja Guru dengan baik dan terencana. 
c. Sebagai data empiris tentang meningkatkan kemampuan guru dalam menyusun dan mengembangkan RPP melalui Kelompok Kerja Guru.

d. Sebagai sumbangan pemikiran untuk pengawas yang ingin meningkatkan kemampuan guru dalam menyusun dan mengembangkan RPP melalui Kelompok Kerja Guru.

\section{Bagi Sekolah}

a. Penelitian ini bermanfaat bagi sekolah karena dapat menjadi bahan masukan dan pertimbangan untuk meningkatkan ketuntasan dan prestasi belajar siswa.

b. Penelitian ini bermanfaat bagi sekolah karena dapat memberi masukan atau sumbangan penelitian bagi peneliti lain yang melakukan Penelitian Tindakan Sekolah (PTS).

c. Penelitian ini bermanfaat bagi sekolah karena dapat memberi masukan atau sumbangan kepada peningkatan kualitas pembelajaran melalui peningkatan kualitas guru dalam menyusun dan mengembangkan RPP yang baik dan terencana.

\section{METODE PENELITIAN}

Penelitian ini merupakan Penelitian Tindakan Sekolah yang dilakukan secara individual. Artinya peneliti melakukan penelitian sendiri baik dari proses awal sampai akhir kegiatan penelitian yang dilakukan langkah demi langkah di dalam sekolah.

Metode yang digunakan dalam penelitian ini adalah Penelitian Tindakan Sekolah (school action research). Penelitian Tindakan Sekolah ini dipilih karena tujuan penelitian ini meningkatkan kemampuan guru dalam menyusun Rencana Pelaksanaan Pembelajaran (RPP). Suharsimi Arikunto (2006) mengatakan bahwa dikarenakan tindakan tersebut dimaksudkan untuk meningkatkan hasil belajar siswa, maka harus berkaitan dengan pembelajaran.

Penelitian ini dilaksanakan selama 5 bulan (Januari s/d Juni 2013) dengan perincian sebagai berikut:

1. Perencanaan tindakan : bulan Januari 2013.

2. Pelaksanaan tindakan : dalam bentuk Kelompok Kerja Guru.

Siklus Pertama dengan dua kali pertemuan yaitu :

a. Pertemuan Pertama (Minggu Ketiga Februari 2013)

b. Pertemuan Kedua (Minggu Keempat Februari 2013)

Siklus Kedua dengan dua kali pertemuan yaitu :

a. Pertemuan Pertama (Minggu

Kedua Maret 2013.

b. Pertemuan Kedua (Minggu

Ketiga Maret 2013) 
3. Penulisan Laporan Hasil Penelitian, Mei 2013.

4. Duplikasi Hasil Penelitian, Mei 2013.

5. Pengesahan Hasil penelitian, Juni 2013.

Obyek penelitian ini adalah guru SDN 166324 Tebing Tinggi berjumlah 45 orang.

Peneliti melakukan kegiatan penelitian ini dalam dua siklus. Setiap Siklus terdiri dari : Perencanaan, Pelaksanaan, Observasi dan Refleksi.

\section{HASIL DAN PEMBAHASAN}

Untuk mengetahui hasil penelitian, langkah pertama yang dilakukan Peneliti adalah mengidentifikasi masalah melalui pengamatan terhadap kemampuan guru dalam merencanakan pembelajaran berupa pengembangan RPP sesuai dengan karakteristik materi ajar dan karakteristik peserta didik sehingga dapat menciptakan pembelajaran yang menyenangkan dan menggairahkan peserta didik (Joyfull Learning).

Siklus Pertama dalam kegiatan penelitian ini mengacu kepada ke empat langkah-langkah tersebut di atas yang dilaksanakan dalam proses penelitian dengan metode Kelompok Kerja Guru yaitu dengan melakukan langkah-langkah sebagai berikut :

1. Pertemuan awal yang dilakukan sebelum melaksanakan observasi kelas. Tujuan utama pertemuan awal ini adalah untuk mengembangkan secara bersamasama antara supervisor dan guru serta kerangka kerja observasi kelas yang akan dilakukan. Hasil pertemuan awal ini adalah kesepakatan (kontrak) kerja antara supervisor dan guru.

2. Tahap observasi pengajaran secara sistematis dan objektif. Perhatian observasi ini ditujukan pada guru ketika mengelola proses belajar mengajar melalui teknik dan instrumen observasi. Dalam observasi ini data sudah dianalisis, aktivitas kelas diklasifikasikan menjadi tiga kategori besar, yakni pembicaraan guru, pembicaraan murid, dan sama sekali tidak ada pembicaraan.

3. Tahap Balikan. Pertemuan balikan ini dilakukan segera setelah melaksanakan analisis hasil observasi pengajaran yang bertujuan menindaklanjuti temuan supervisor, sebagai observer terhadap proses belajar mengajar secara deskriptif, spesifik, konkret, bersifat memotivasi, aktual, dan akurat, sehingga betul-betul bermanfaat. Dalam pertemuan balikan, supervisor memberikan penguatan (reinforcement) kepada guru kemudian bersama-sama menganalisis setiap aspek 
pengajaran yang menjadi perhatian Kelompok Kerja Guru.

Data yang dikumpulkan untuk dianalisis dalam penelitian ini adalah data kualitatif dan kuantitatif. Data kualitatif yang dikumpulkan adalah data yang menggambarkan keaktifan guru, antusias guru, partisipasi, dan kerjasama dalam berdiskusi. Data kuantitatif yang dikumpulkan adalah data yang menggambarkan kemampuan guru merencanakan dan melaksanakan pembelajaran berupa pengembangan RPP. Instrumen penelitian yang digunakan dalam penelitian ini berupa:

1. Lembar observasi,

2. Instrumen penilaian kinerja guru

3. Catatan peneliti selama proses penelitian.

Analisis data yang dilakukan dalam penelitian ini menggunakan statistik deskriptif sederhana yaitu berupa penghitungan nilai dan mengklasifikasikannya.

Penghitungan rerata dari setiap kelompok data yang diperoleh dari subjek penelitian. Dari hasil penghitungan rerata ini dapat digambarkan kondisi subjek sumber data tersebut diperoleh.

Pada tahap ini peneliti mendesain Kelompok Kerja Guru dengan perencanaan tindakan yang berlangsung dalam suatu siklus yang dimulai pada tahap pertama yakni: pertemuan awal yang terdiri dari:

a. Pada awal penelitian dilaksanakan terlebih dahulu pertemuan dengan guru-guru. Pada tahap ini peneliti menjelaskan akan melaksanakan Kelompok Kerja Guru kepada guru-guru. Dan menjelaskan bagaimana Kelompok Kerja Guru itu. Penjelasan-penjelasan yang disampaikan diusahakan tidak menimbulkan kesan negatif dari guru. Pada tahap ini sebisanya dilaksanakan suasana intim dan terbuka sehingga tercipta suasana kolegalitas yang akrab seperti hubungan antara teman sejawat bukan hubungan antara atasan dan bawahan karena peneliti sebagai supervisor merupakan Pengawas sekolah. Kondisi seperti ini diharapkan nantinya guru-guru akan mengutarakan pendapatnya secara terbuka dan bersedia untuk menerima perbaikan.

b. Setelah tercipta hubungan yang harmonis antara guru dan supervisor untuk selanjutnya mulailah mengkaji rencana pembelajaran yang meliputi tujuan, metode, waktu, media, evaluasi belajar, dll yang terkait dengan pembelajaran.

c. Guru bersama supervisor menentukan fokus perhatian observasi. 
d. Menentukan alat bantu (instrumen) observasi yang akan digunakan atau memakai instrument yang sudah ada.

e. Menentukan teknis pelaksanaan observasi.

Perencanaan pada siklus pertama ini dilakukan dalam bentuk Pertemuan awal yang dilakukan sebelum melaksanakan observasi kelas. Tujuan utama pertemuan awal ini adalah untuk mengembangkan secara bersama-sama antara supervisor dan guru serta kerangka kerja observasi kelas yang akan dilakukan. Hasil pertemuan awal ini adalah kesepakatan (kontrak) kerja antara supervisor dan guru. Dalam pertemuan awal ini disepakati ada 5 guru bidang studi yang menjadi sampel penelitian yaitu :

1. Bidang Studi Ilmu Pengetahuan Alam

2. Bidang Studi Bahasa Inggris

3. Bidang Studi Matematika

4. Bidang Studi Bahasa Indonesia

5. Bidang Studi Agama Islam

Dari pertemuan awal ini juga telah disepakati bersama bahwa antara guru dengan supervisor (Pengawas Sekolah) mempunyai komitmen untuk melakukan penelitian tentang upaya meningkatkan kemampuan guru di SDN 166324 Tebing Tinggi dalam merencanakan pembelajaran berupa pengembangan RPP melalui Kelompok Kerja Guru.
Dalam penelitian ini, Pengawas Sekolah sebagai Supervisor dan 5 orang guru bidang studi menjadi sampel penelitian yang akan disupervisi. Pada pertemuan awal ini juga dibahas tentang kerangka kerja observasi kelas yang akan dilakukan oleh Supervisor . Pada tahap ini juga didiskusikan tentang mekanisme pengumpulan data yang akan dilakukan oleh peneliti dengan sampel penelitian yaitu dengan metode observasi, kuesioner dan wawancara mendalam.

Pada tahap ini tindakan yang dilakukan adalah Kelompok Kerja Guru yakni tahap pengamatan/observasi saat guru mengajar yang terdiri dari:

a. Supervisor harus luwes saat melakukan observasi agar tidak mengganggu proses pembelajaran.

b. Supervisor membuat semacam rekaman tertulis.(verbatim transcript). Transkrip ini bisa dittulis langsung berdasarkan pengamatan dan bisa juga disalin dari apa yang direkam terlebih dahulu melalui tape recorder.

c. Rekaman observasional berupa seating chart. Supervisor mendokumentasikan perilaku peserta didik sebagaimana mereka berinteraksi dengan guru selama proses pembelajaran.

d. Supervisor membuat catatan lengkap mengenai kejadiankejadian di kelas selama proses 
pembelajaran sesuai kesepakatan bersama.

e. Supervisor mengobservasi dan mengumpulkan data perilaku belajar mengajar. Dalam analisis ini, aktivitas kelas diklasifikasikan menjadi tiga kategori besar, yakni pembicaraan guru, pembicaraan murid, dan sama sekali tidak ada pembicaraan.Pada tahap ke dua ini, peneliti melakukan observasi pengajaran secara sistematis dan objektif setelah seluruh instrumen atau alat pengumpul data disusun. Sebelum memecahkan masalah dalam penelitian ini ada tiga metode pengumpulan data dan fakta yang dilakukan peneliti yaitu melalui Observasi, Kuesioner dan Wawancara. Dalam kegiatan observasi peneliti melakukan pengumpulan data melalui lembar observasi yang akan menggali temuan aktivitas guru dalam proses menyusun RPP (KBM). Observasi tentang pengajaran ini akan dilakukan secara sistematis dan objektif.Ada tiga aspek yang dinilai / disupervisi dalam proses menyusun RPP (KBM) yaitu : Administrasi, Penampilan dan RPP.

Belajar Mengajar (KBM) pada Siklus Pertama

Pada tahap ini peneliti mengadakan pengamatan terhadap guru-guru untuk setiap kali pertemuan. Tindakan yang ketiga ini sudah dilaksanakan pada tahap kedua. Data yang tadinya sudah terekam dan tercatat pada saat observasi kemudian dianalisis untuk didiskusikan pada tahap refleksi. Di samping itu pula pada tahap ini juga dihasilkan catatan-catatan penting tentang keunggulan maupun kelemahan Kelompok Kerja Guru.

Ada tiga aspek yang dinilai/disupervisi dalam proses menyusun RPP (KBM) yaitu : Administrasi, Penampilan dan RPP.

Dalam penelitian ini ada 5 bidang studi yang menjadi sampel yaitu Ilmu Pengetahuan Alam, Bahasa Inggris, Matematika, Bahasa Indonesia dan Pendidikan Agama Islam.

Pengumpulan data dan fakta dalam aspek administrasi ini dilakukan melalui Observasi. (Mengacu kepada Instrumen Format 1 Lembar Observasi). Adapun komponen-komponen yang dinilai adalah :

a. Perencanaan Proses Pembelajaran Menyusun RPP

b. Pelaksanaan Proses Pembelajaran

c. Penilaian Hasil Belajar

d. Pengawasan Proses Pembelajaran Berdasarkan hasil observasi diperoleh data dan fakta bahwa dalam kegiatan Proses Menyusun RPP (KBM) dari aspek Administrasi: Menyusun Sillabus, Menyusun RPP, Pelaksanaan Proses Pembelajaran, Penilaian Hasil Belajar dan Pengawasan Proses 
pembelajaran secara rata-rata dari guru ke 5 bidang studi tersebut memperoleh hasil Cukup (51- 75). Artinya, para guru yang mengasuh ke 5 bidang studi tersebut mempunyai kemampuan yang Cukup dalam mempersiapkan proses menyusun RPP (KBM) dari aspek Administrasi.

Adapun kekurangan yang terjadi pada guru dari aspek administratif berdasarkan hasil observasi ini adalah terlihat guru tidak mempunyai persiapan dalam hal membuat kompetensi dasar menyusun Silabus. Selain itu, guru juga terlihat Kurang Baik dalam membuat Identitas mata pelajaran atau tema pelajaran dan Alokasi Waktu ketika menyusun Sillabus.

Sedangkan aspek yang lain dalam proses menyusun RPP (KBM) dari aspek Administrasi, dalam hal ini menyusun RPP para guru ke lima bidang studi tersebut memiliki kemampuan Cukup. Namun, ketika peneliti menggali lebih dalam melalui wawancara secara in-formal tentang sumber atau referensi mereka menyusun RPP ternyata ke lima guru tersebut masih belum benar-benar menguasai isi RPP nya terutama dalam menentukan Indikator Pencapaian Kompetensi, Metode dan Model Pembelajaran. Sedangkan yang Sangat Baik dilakukan oleh guru dalam kaitannya dengan proses menyusun RPP (KBM) dari aspek Administrasi adalah ketika berlangsung pelaksanaan proses pembelajaran yaitu persyaratan pelaksanaan proses pembelajaran dan pelaksanaan pembelajaran

Adapun hasil observasi dari aspek Penampilan yang dilakukan kepada 5 orang guru dari 5 bidang studi tersebut memperlihatkan pada tahap sebelum observasi, ke lima guru tersebut ternyata termasuk dalam kategori Cukup (51-75) untuk mempersiapkan bahan pelajaran yang akan diajarkan kepada siswanya. Mereka juga memahami konsep yang dibahas dan tujuan yang akan dicapai dari proses pembelajaran itu dengan baik. Para guru juga melakukan langkahlangkah penyajian materi pelajaran secara sistematis yang dimulai dari pendahuluan, inti dan penutup dengan baik. Demikian juga halnya dengan pemanfaatan media pembelajaran, guru menggunakannya dengan baik. Proses interaksi yang dilakukan guru dengan siswa ketika KBM berlangsung ternyata juga berlangsung dengan Baik.

Pada tahap pelaksanaan observasi, hasil yang diperoleh juga termasuk dalam kategori Baik. Artinya, kelima guru bidang studi tersebut mempunyai kejelasan konsep dalam proses menyusun RPP (KBM) dengan baik. Tingkat keberhasilan yang baik serta menggunakan media pembelajaran dengan baik. Efektivitas Interaksi 
yang dilakukan ketika KBM berlangsung juga berhasil dengan baik.

Demikian juga halnya, hasil observasi pada tahap sesudah observasi, peneliti menilai kesankesan penampilan dari guru ketika mengajar termasuk dalam kategori baik. Pada tahap sesudah observasi ini, berdasarkan wawancara dan observasi yang peneliti lakukan kepada kelima guru bidang studi tersebut ternyata kemampuan mengidentifikasi keterampilan yang sudah berhasil dengan kemampuan mengidentifikasi keterampilan yang belum berhasil juga baik. Dalam hal ini guru sudah dapat memilah aspekaspek apa yang sudah baik dalam KBM dan yang perlu ditingkatkan. Berdasarkan hasil wawancara peneliti dengan para guru tersebut yang perlu ditingkatkan antara lain adalah: pengadaan media pembelajaran dan kualitas sumber daya manusia, dalam hal ini tentunya guru perlu lebih ditingkatkan kemampuannya dan profesionalismenya.

Pengumpulan data untuk memperoleh hasil tes dilakukan dengan menyusun kuesioner dan dibagikan kepada guru di SDN 166324 Tebing Tinggi yang berjumlah 41 orang. Berdasarkan hasil kuesioner pada siklus pertama maka terlihat temuan fakta sebagai berikut :

Hasil Test Proses Menyusun RPP (KBM)

\begin{tabular}{|c|c|c|c|}
\hline No. & Aspek yang diamati & Jumlah & Rata-rata \\
\hline 1 & Memeriksa Kesiapan Siswa & 136 & 2,72 \\
\hline 2 & Melakukan kegiatan apersepsi & 119 & 2,38 \\
\hline 3 & $\begin{array}{l}\text { Mengaitkan materi pembelajaran dengan } \\
\text { pengetahuan yang relevan }\end{array}$ & 138 & 2,76 \\
\hline 4 & $\begin{array}{l}\text { Menyampaikan materi dengan jelas dan sesuai } \\
\text { dengan hierarkhi belajar }\end{array}$ & 143 & 2,86 \\
\hline 5 & $\begin{array}{l}\text { Mengaitkan materi pembelajaran dengan realitas } \\
\text { kehidupan }\end{array}$ & 135 & $\mathbf{2 , 7 0}$ \\
\hline 6 & $\begin{array}{l}\text { Melaksanakan pembelajaran sesuai dengan } \\
\text { kompetensi yang akan dicapai }\end{array}$ & 135 & 2,70 \\
\hline 7 & Melaksanakan pembelajaran secara runtut & 126 & 2,52 \\
\hline 8 & Melaksanakan pembelajaran bersifat kontekstual & 119 & 2,38 \\
\hline 9 & $\begin{array}{l}\text { Siswa memberikan respon bertanya atau } \\
\text { menjawab pertanyaan }\end{array}$ & 114 & 2,28 \\
\hline
\end{tabular}


ESJ VOLUME 6, NO. 1, DESEMBER 2016

\begin{tabular}{|c|c|c|c|}
\hline 10 & $\begin{array}{l}\text { Menyesuaikan dengan alokasi waktu yang } \\
\text { direncanakan }\end{array}$ & 117 & 2,34 \\
\hline 11 & Menggunakan media peraga saat pembelajaran & 99 & 198 \\
\hline 12 & $\begin{array}{l}\text { Melibatkan siswa dalam penggunaan media } \\
\text { pembelajaran }\end{array}$ & 95 & 1,90 \\
\hline 13 & $\begin{array}{llll}\text { Muncul partisipasi } & \text { aktif } & \text { siswa } & \text { dalam } \\
\text { pembelajaran }\end{array}$ & 114 & 2,28 \\
\hline 14 & $\begin{array}{l}\text { Memantau kemajuan belajar siswa selama proses } \\
\text { pembelajaran }\end{array}$ & 121 & 2,42 \\
\hline 15 & $\begin{array}{l}\text { Melakukan penilaian akhir setiap mengakhiri } \\
\text { proses pembelajaran }\end{array}$ & 120 & 2,4 \\
\hline 16 & $\begin{array}{l}\text { Menggunakan model-model pembelajaran saat } \\
\text { melaksanakan pembelajaran }\end{array}$ & 109 & 2,18 \\
\hline 17 & $\begin{array}{l}\text { Selalu menumbuhkan keceriaan dan antusiasme } \\
\text { siswa dalam belajar }\end{array}$ & 112 & 2,24 \\
\hline 18 & $\begin{array}{l}\text { Selalu membuat lembaran kerja/lembaran tugas } \\
\text { saat proses pembelajaran }\end{array}$ & 117 & 2,34 \\
\hline 19 & $\begin{array}{l}\text { Melakukan refleksi atau membuat rangkuman } \\
\text { materi dengan melibatkan siswa }\end{array}$ & 113 & 2,26 \\
\hline 20 & $\begin{array}{l}\text { Melaksanakan tindak lanjut dengan memberikan } \\
\text { arahan, atau kegiatan, atau tugas sebagai bagian } \\
\text { remedi / pengayaan }\end{array}$ & 112 & 2,24 \\
\hline & Jumlah & 2406 & \\
\hline & Rata-rata & & 48,2 \\
\hline
\end{tabular}

Berdasarkan hasil analisis data yang dilakukan kepada 41 orang guru di SDN 166324 Tebing Tinggi diperoleh nilai rata-rata sebesar 48,2. Data ini memperlihatkan bahwa kemampuan guru di SDN 166324 Tebing Tinggi dalam mempersiapkan proses menyusun RPP (KBM) termasuk dalam kategori Sedang. Hal ini berdasarkan pada penetapan 4 kategori yang disusun sebagai berikut dengan interval sebesar 15 yang diperoleh berdasarkan rumus sebagai berikut :

(Nilai Tertinggi - Nilai Terendah)

Jumlah Kategori (4)

$20-35=$ Rendah/Tidak Pernah
$36-51=$ Kurang/Kadang-kadang

$52-67=$ Cukup/Sering

$68-83=$ Baik $/$ Sangat Sering

Sedangkan apabila dianalisis berdasarkan indikator yang diamati ada beberapa aspek yang perlu ditingkatkan dari kemampuan guru dalam pengelolalan pembelajaran di kelas yaitu diantaranya pada aspek melibatkan siswa dalam penggunaan media pembelajaran, yaitu dengan nilai rata-rata 1,90 . Data ini memperlihatkan bahwa kemampuan guru di SDN 166324 Tebing Tinggi melibatkan siswa dalam penggunaan media pembelajaran termasuk dalam 
kategori Kurang/Kadang-kadang. Hal ini berdasarkan pada penetapan 4 kategori yang disusun sebagai berikut dengan interval sebesar 0,75 yang diperoleh berdasarkan rumus sebagai berikut:

(Nilai Tertinggi - Nilai Terendah) Jumlah Kategori (4)

1-175 = Rendah $/$ Tidak Pernah

176-2,51 = Kurang/Kadang-kadang

2,52-3,27 = Cukup/Sering

$3,28-4,03=$ Baik/Sangat Sering.

Demikian juga halnya dengan kesiapan dan kemampuan guru menggunakan media peraga saat pembelajaran terlihat juga termasuk dalam kategori Kurang / Kadang-kadang dengan perolehan nilai rata-rata hanya sebesar 1,98. Data yang diperoleh melalui hasil tes pada kondisi awal terlihat ada juga beberapa aspek yang termasuk Kategori Cukup / Sering yaitu guru menyampaikan materi dengan jelas dan sesuai dengan hierarkhi belajar dengan perolehan nilai rata-rata sebesar 2,86. Selain itu, aktivitas guru untuk Memeriksa Kesiapan Siswa, Mengaitkan materi pembelajaran dengan realitas kehidupan dan Melaksanakan pembelajaran sesuai dengan kompetensi yang akan dicapai ternyata termasuk dalam kategori Cukup / Sering.

Seperti pada Siklus pertama, maka pada siklus Kedua ini, supervisor mempunyai peran sebagai seseorang yang mampu menciptakan hubungan yang harmonis, siap memberikan bantuan dan pertolongan, memahami kebutuhan dan berkonsentrasi terhadap kebutuhan guru yang berhubungan dengan pengembangan kegiatan belajar mengajar (KBM).

Demikian juga halnya yang dilakukan oleh supervisor/pengawas sekolah yang melakukan penelitian ini dalam diskusi balikan pada tahap ke dua. Peneliti mengakomodir semua pendapat, masukan, kritikan serta harapan yang disampaikan oleh guru dalam pertemuan balikan tersebut yang pada siklus pertama masih belum dapat didiskusikan secara mendalam dan tuntas. Peneliti menyadari bahwa metode Kelompok Kerja Guru merupakan layanan yang memfokuskan pada perbaikan pengajaran dengan menjalankan siklus yang sistematis dari tahap perencanaan, pengamatan, dan analisis intelektual yang.intensif terhadap penampilan pengajar dengan tujuan untuk modifikasi yang rasional. Pada siklus kedua ini, peneliti mencoba mngaplikasikan hal tersebut secara lebih intensif.

$$
\text { Untuk menjalankan }
$$

Kelompok Kerja Guru peneliti menyadari diperlukan iklim kerja yang baik, sebab faktor yang sangat menentukan keberhasilan Kelompok Kerja Guru adalah kepercayaan guru bahwa tugas supervisor semata-mata 
untuk membantu guru mengembangkan pengajarannya. Sebagai upaya memperoleh kepercayaan dari guru peneliti juga berusaha membangun hubungan iklim kerja yang disebut dengan istilah kolegial. Pada siklus kedua ini, penulis mencoba lebih mengaplikasikan hal tersebut dalam pembicaraan-pembicaraan yang bersifat informal.

Pada Siklus Kedua ini, peneliti juga memberikan penguatan terhadap perihal positif yang dilakukan oleh guru. Penguatan diberikan sebagai respon yang diberikan Supervisor terhadap perilaku guru yang baik, sehingga guru terdorong untuk mengulangi atau meningkatkan perilaku yang lebih baik lagi. Penguatan diberikan dengan tujuan meningkatkan motivasi guru untuk meningkatkan kualitas dalam pembelajaran, mencegah perilaku yang negatif, menumbuhkan rasa percaya diri, serta memelihara iklim kelas yang kondusif. Pada Siklus kedua ini, peneliti mencoba menggali lebih dalam dan spesifik aspek-aspek apa saja yang dapat ditingkatkan dari kemampuan guru di SDN 166324 Tebing Tinggi.

\section{SIMPULAN}

Adapun simpulan dari hasil penelitian ini ialah:

1. Berdasarkan hasil observasi diperoleh data dan fakta bahwa dalam kegiatan proses

Pengadaan Kegiatan Belajar Mengajar (KBM) dari aspek Administrasi : Menyusun Silabus, Menyusun dan mengembangkan RPP, Pelaksanaan Proses Pembelajaran, Penilaian Hasil Belajar dan Pengawasan Proses pembelajaran secara rata-rata dari guru ke 5 bidang studi tersebut memperoleh hasil Cukup (51-75). Artinya, para guru yang mengasuh ke 5 bidang studi tersebut mempunyai kemampuan yang Cukup Baik dalam mempersiapkan Proses Pengadaan Kegiatan Belajar Mengajar (KBM) dari aspek

2. Adapun kekurangan yang terjadi pada guru dari aspek administratif berdasarkan hasil observasi ini adalah terlihat guru tidak mempunyai persiapan dalam hal membuat kompetensi dasar menyusun Silabus. Selain itu, guru juga terlihat Kurang Baik dalam membuat Identitas mata pelajaran atau tema pelajaran dan Alokasi Waktu ketika menyusun Sillabus.

3. Kekurangan lainnya dari aspek administrasi adalah dari sumber atau referensi mereka menyusun dan mengembangkan RPP ternyata ke lima guru tersebut masih belum benar-benar menguasai isi RPP nya terutama dalam menentukan Indikator 
Pencapaian Kompetensi, Metode dan Model Pembelajaran.

4. Sedangkan yang sangat Baik dilakukan oleh guru dalam kaitannya dengan proses pengadaan kegiatan belajar mengajar (KBM) dari aspek administrasi adalah ketika berlangsung pelaksanaan proses pembelajaran yaitu persyaratan pelaksanaan proses pembelajaran dan pelaksanaan pembelajaran.

5. Adapun hasil observasi dari aspek penampilan yang dilakukan kepada 5 orang guru dari 5 bidang studi tersebut memperlihatkan pada tahap sebelum observasi, ke lima guru tersebut ternyata termasuk dalam kategori Baik (61-80) untuk mempersiapkan bahan pelajaran yang akan diajarkan kepada siswanya. Mereka juga memahami konsep yang dibahas dan tujuan yang akan dicapai dari proses pembelajaran itu dengan baik. Para guru juga melakukan langkah-langkah penyajian materi pelajaran secara sistematis yang dimulai dari pendahuluan, inti dan penutup dengan baik. Demikian juga halnya dengan pemanfaatan media pembelajaran, guru menggunakannya dengan baik. Proses interaksi yang dilakukan guru dengan siswa ketika KBM berlangsung ternyata juga berlangsung dengan Baik.
6. Hasil observasi dari aspek penampilan yang dilakukan pada tahap pelaksanaan observasi, hasilnya juga termasuk dalam kategori Baik . Artinya, kelima guru bidang studi tersebut mempunyai kejelasan konsep dalam proses pengadaan Kegiatan Belajar Mengajar (KBM) dengan baik. Tingkat keberhasilan yang baik serta menggunakan media pembelajaran dengan baik. Effektivitas Interaksi yang dilakukan ketika KBM berlangsung juga berhasil dengan baik.

7. Demikian juga halnya, hasil observasi dari aspek penampilan pada tahap sesudah Kelompok Kerja Guru, peneliti menilai kesan-kesan penampilan dari guru ketika mengajar termasuk dalam kategori baik.

8. Berdasarkan hasil analisis data yang dilakukan kepada 41 orang guru di SDN 166324 Tebing Tinggi tentang kemampuan mereka dalam mempersiapkan pengadaan kegiatan belajar mengajar diperoleh nilai rata-rata sebesar 48,2. Data ini memperlihatkan bahwa kemampuan guru di SDN 166324 Tebing Tinggi dalam mempersiapkan proses pengadaan Kegiatan Belajar Mengajar (KBM) termasuk dalam kategori Sedang. 
9. Sedangkan apabila dianalisis berdasarkan indikator yang diamati ada beberapa aspek yang perlu ditingkatkan dari kemampuan guru dalam pengelolalan pembelajaran di kelas yaitu diantaranya pada aspek melibatkan siswa dalam penggunaan media pembelajaran, yaitu dengan nilai rata-rata 1,90. Data ini memperlihatkan bahwa kemampuan guru di SDN 166324 Tebing Tinggi melibatkan siswa dalam penggunaan media pembelajaran termasuk dalam kategori Kurang/Kadang-kadang.

10. Pada Siklus kedua, guru menyadari bahwa terbatasnya dukungan media pembelajaran di SDN 166324 Tebing Tinggi sehingga guru kesulitan menerapkan metode pembelajaran yang inovatif sesuai dengan kebutuhan siswa yaitu suasana belajar yang menyenangkan bagi siswa. Selain itu juga, guru merasakan target kurikulum yang harus dicapai juga sangat padat tidak sesuai dengan alokasi waktu yang diberikan. Alternatif untuk mengatasi kesulitan ini guru merasa sangat membutuhkan pendidikan dan pelatihan yang relevan dengan peningkatan profesionalisme mereka dalam KBM.

11. Komitmen lainnya yang terungkap dalam diskusi balikan pada Siklus kedua setelah Kelompok Kerja Guru dilaksanakan adalah guru akan meningkatkan kemampuannya mengadakan variasi dalam teknik mengajar, meningkatkan kemampuan mengelola dan disiplin kelas, mengajar atas dasar kemampuan dan potensi diri siswa secara individu serta berusaha optimal untuk mengembangkan kreativitas siswa.

12. Peserta Kelompok Kerja Guru yaitu Guru di SDN 166324 Tebing Tinggi memberikan respon dan tanggapan positif terhadap kegiatan penetapan Kriteria Ketuntasan Minimal melalui Kelompok Kerja Guru. Dengan demikian kegiatan Kelompok Kerja Guru dapat meningkatkan keterampilan Guru dalam menyusun dan mengembangkan RPP melalui Kelompok Kerja Guru.

Berdasarkan hasil penelitian yang diperoleh, dapat disarankan beberapa hal, antara lain :

1. Kegiatan Kelompok Kerja Guru untuk meningkatkan keterampilan guru dalam menyusun dan mengembangkan RPP hendaknya dapat dilakukan secara periodik agar kualitas dan keterampilannya dapat terjaga dengan baik.

2. Melalui pengetahuan dan keterampilan yang diperoleh 
Guru melalui kegiatan Kelompok Kerja Guru sebaiknya para guru dapat menyusun RPP dengan memperhatikan mekanisme yang sebenarnya yaitu prinsip dan langkahlangkah penetapan penyusunan RPP.

3. Dalam kegiatan Kelompok Kerja Guru ini sebaiknya semua Guru harus mampu bekerja sama dengan peserta lain yang bersifat kolaboratif konsultatif, sehingga hasil Kelompok Kerja Guru dapat berjalan dengan effektif.

4. Pihak sekolah sebaiknya secara rutin dapat memfasilitasi Kelompok Kerja Guru peningkatan keterampilan guru dalam menyusun RPP agar kemampuan dan keterampilan guru dalam menyusun RPP dapat terjaga dengan baik.

5. Pemerintah dalam hal ini Departemen Pendidikan dan Kebudayaan yang berada di Pusat dan Dinas Pendidikan di Propinsi serta di Kabupaten/ Kota hendaknya senantiasa memfasilitasi semua kegiatan guru dalam rangka meningkatkan keterampilan menyusun RPP.

\section{DAFTAR RUJUKAN}

Abdullah, A,E. 1989. Pokok-pokok Layanan Bimbingan Belajar. Ujung Pandang; Fakultas Ilmu Pendidikan IKIP Ujung Pandang.

Abdurrahman, H. 1990. Pengelolaan Pengajaran. Bandung Tarsito.

Ahmadi, Abu. 1998. Didaktik Metodik. Semarang: CV. Toha Putra.

Ali, M. 1993. Guru dan Proses Belajar Mengajar. Bandung: Sinar Baru Algesindo.

Arikunto, S. 1993. Prosedur Penelitian dan Penilaian Hasil Belajar. Jakarta: Bina Aksara.

Boediono, 1998. Pembinaan Profesi Guru dan Psikologi Pembinaan Personalia. Jakarta: Departemen Pendidikan dan Kebudayaan.

Bahri, D.S. 1997. Prestasi Belajar dan Kompetensi Guru. Surabaya: Usaha nasional.

Edward., J.D. 1995.Statistik Matematika Modern. Jakarta: PT. Gramedia Pustaka Utama.

Gie. 1995. Cara Belajar yang Efisien. Yogyakarta: Liberti.

Hardjana. 1994. Kiat Sukses di Perguruan Tinggi. Yogyakarta: Kanisius. 
Hudoyo, H. 1984. Pengembangan Kurikulum. Surabaya: Usaha Nasional.

Loekmono. $1994 . \quad B e l a j a r$ Bagaimana Belajar. Jakarta: BPK Gunung Mulia.

Mappa, S. 1970. Psikologi Pendidikan. Ujung pandang: Fakultas Ilmu pendidikan IKIP Ujung pandang.

Mardanu. 1997.Peranan Orang Tua dalam Upaya Meningkatkan Mutu Pendidikan Anak. Jakarta: Cakrawala Pendidikan.

Muhtar. 1992.Pedoman Bimbingan Guru dalam Proses Belajar Mengajar. Jakarta: PGK \& PTK Dep.Dikbud.

Mathis dan Jackson. 2002. Manajemen Sumber Daya Manusia. Jakarta : Salemba Empat.

Nasution, S. 1988. Berbagai Pendekatan dalam Proses Belajar MengajarJakarta. PT. Bina Aksara.

Nurkancana, W.J.S. 19837. Kamus Umum Bahasa Indonesia. Jakarta: Balai Pustaka.
Sardiman, A.M. 1992. Interaksi dan Motivasi belajar mengajar. Jakarta: CV Rajawali Press.

Slameto. 1995. Belajar dan FaktorFaktor yang Mempengaruhi. Jakarta : Rineka Cipta.

Sardiman, A.M. 1992.Interaksi dan Motivasi Belajar Mengajar. Jakarta: Rajawali Pers.

Slameto. 1995. Belajar dan Faktorfaktor yang Mempengaruhinya. Jakarta: Rineka Cipta. 1995.

Sudarmono. 1994. Tuntunan Metodologi Belajar. Jakarta: Grasindo.

Syah, Muhibbin. Psikologi Pendidikan Suatu Pendekatan Baru. Jakarta: Logos Wacana Ilmu.

Sudibyo, Bambang. 2002. Model dan Teknik Penilaian pada Tingkat Satuan Pendidikan Dasar dan Menengah. Jakarta: Departemen Pendidikan Nasional.

Sungkowo M. 2003.Perangkat Penilaian Kurikulum Tingkat satuan Pendidikan Sekolah Menengah Atas. Jakarta: Departemen Pendidikan Nasional. 